\title{
PENGARUH RETURN ON ASSET, EARNING PER SHARE, DAN PRICE EARNING RATIO TERHADAP RETURN SAHAM PERUSAHAAN MANUFAKTUR SUB SEKTOR INDUSTRI ROKOK YANG TERDAFTAR DI BURSA EFEK INDONESIA
}

\author{
ASTRID RAVITASARI BLONGKOD \\ ARIAWAN \\ PEMY CHRISTIAN \\ Jurusan Manajemen, Fakultas Ekonomi, Universitas Ichsan Gorontalo \\ ariawan@unisan.ac.id
}

\begin{abstract}
The study intends to determine simultaneous and partial influence of Return On Asset $\left(X_{1}\right)$, Earning Per Share $\left(X_{2}\right)$ and Price Earning Ratio $\left(X_{3}\right)$ on return share of manufacturing company sub sector cigarettes industry listed on Indonesia Stock Exchange. Data used is secondary data that is gathered from Indonesia Stock Exchange Website. Technique of data analysis is multiple linear regressions, which is proceeded with E-Views program version 9. The result of study confirms that partially, Return On Asset (ROA) and Price Earning Ratio (PER) have non-significant influence on Return Share in manufacturing company sub sector cigarrettes industry listed on Indonesia Stock Exchange during the period of 2012-2016 while Earning Per Share (EPS) has significant influence on Return Share. Simultaneously, Return On Asset (ROA), Earning Per Share (EPS), and Price Earning Ratio (PER) show significant influence on Return Share in manufacturing company sub sector cigarrettes industry listed on Indonesia Stock Exchange in the period of 2012-2016 by 20,2328\%.
\end{abstract}

Keywords: Return On Asset, Earning Per Share, Price Earning Ratio, and Return Saham

\begin{abstract}
ABSTRAK
Penelitian ini bertujuan untuk mengetahui pengaruh Return On Asset $\left(\mathrm{X}_{1}\right)$, Earning Per Share $\left(\mathrm{X}_{2}\right)$ dan Price Earning Ratio $\left(\mathrm{X}_{3}\right)$ secara simultan dan parsial terhadap Return Saham Perusahaan Manufaktur Sub Sektor Industri Rokok Yang Terdaftar di Bursa Efek Indonesia. Data dalam penelitian ini merupakan data sekunder. Pengumpulan data diperoleh dari situs Bursa Efek Indonesia. Teknik analisis data menggunakan regresi berganda yang diolah menggunakan program E-Views versi 9. Hasil Penelitian menunjukan bahwa Secara parsial Return On Asset (ROA) tidak berpengaruh signifikan terhadap Return saham pada Perusahaan Manufaktur Sub Sektor Industri Rokok yang Terdaftar di BEI selama periode 2012-2016. Earning Per Share (EPS) berpengaruh signifikan terhadap Return saham pada Perusahaan Manufaktur. Price Earning Ratio (PER) tidak berpengaruh signifikan terhadap Return saham pada Perusahaan Manufaktur Sub Sektor Industri Rokok yang Terdaftar di BEI periode 2012-2016. Secara simultan menunjukan bahwa Return On Asset (ROA), Earning Per Share (EPS), Price Earning Ratio (PER) secara bersama-sama berpengaruh signifikan terhadap variabel terikat Return saham Perusahaan Manufaktur Sub Sekor Industri Rokok yang Terdaftar di BEI periode 2012-2016 dengan besar pengaruh yakni sebesar 20,2328\%.
\end{abstract}

Kata Kunci: Return On Asset, Earning Per Share, Price Earning Ratio, Return Saham

\section{PENDAHULUAN}

Return saham perusahaan cenderung berfluktuatif, dimana kadang kala terjadi keuntungan (bernilai positif) kadang pula terjadi kerugian (bernilai negatif). Berbagai keadaan yang terjadi pada Return saham tersebut tentunya ada faktor yang mempengaruhi. Hal tersebut sebagaimana dikatakan oleh Sudarsono dan Sudiyatno (2016: 30) menyatakan bahwa banyak faktor yang mempengaruhi Return saham, diantaranya Faktor-faktor fundamental tersebut yakni Return On Asset (ROA), Earning Per Share (EPS) dan Price Earning Ratio (PER).

Return On Asset (ROA) atau Return On Invesment (ROI) dalam penelitian ini adalah mengukur perbandingan antara laba bersih setelah dikurangi beban bunga dan pajak (Earning After Taxes/EAT) yang dihasilkan dari kegiatan pokok perusahaan dengan total aktiva (assets) yang dimiliki perusahaan. 
Hubungan antara Return On Asset (ROA) dengan return saham sebagaimana dijelaskan oleh Şebnem Er dan Bengü Vuran (2012) bahwa Return On Asset (ROA) dapat menjadi faktor yang dapat meningkatkan nilai perusahaan yang diukur dengan return saham.

Earning Per Share (EPS). adalah salah satu rasio pasar yang merupakan hasil atau pendapatan yang akan diterima oleh para pemegang saham untuk setiap lembar saham yang dimilikinya atas keikutsertaan dalam perusahaan. Keterkaitan antara Earning Per Share (EPS) dengan return saham sebagaimana dijelaskan oleh Nathaniel (2008:41) bahwa investor akan mengharapkan manfaat dari investasinya dalam bentuk laba per lembar saham, sebab Earning per Share (EPS) yang akan didistribusikan kepada investor saham.

Malintan (2012:7) menjelaskan bahwa PER digunakan oleh para investor untuk memprediksi kemampuan perusahaan dalam menghasilkan laba di masa yang akan datang. Jika harga saham semakin tinggi maka selisih harga saham periode sekarang dengan periode sebelumnya semakin besar, sehingga capital gain juga semakin meningkat. Hal ini berarti PER berpengaruh positif terhadap Return saham.

Terkait dengan Return saham, maka penelitian ini dilakukan pada perusahaan Rokok yang terdaftar pada Bursa Efek Indonesia. Rata-rata perusahaan mengalami fluktuatif yakni terjadi kenaikan dan penurunan yang cukup signifikan. Hal tersebut dapat dilihat pada perusahaan PT Gudang Garam Tbk dimana pada tahun 2012 dan 2013 terjadi penurunan harga saham sehingga nilai Return saham yakni negatif. Kemudian dapat pula dilihat pada perusahaan PT HM Sampoerna Tbk tahun 2016 yang mengalami penurunan sebesar 7,49\% dari tahun 2015. Sementara itu untuk perusahaan PT Bentoel International Investama juga demikian yang mengalami penurunan pada tahun 2012, 2013 serta tahun 2015. Kemudian untuk perusahaan PT Wismilak Inti Makmur Tbk yang mengalami penurunan harga dan Return saham pada tahun 2013-2015.

Masalah mengenai return saham tersebut tentunya terjadi karena berbagai faktor sebagaimana dijelaskan dalam teori dan kajian relevan. Salah satu faktor tersebut yakni Return On Asset (ROA) dimana keuntungan perusahaan cenderung stabil kecuali untuk perusahaan PT Bentoel International Investama Tbk yang selama 5 tahun terkahir terus mengalami kerugian. masalah yang paling krusial yakni perusahaan yang tidak mampu menghasilkan keuntungan (rugi). Hal ini sebagai akibat dari berbagai hal diantaranya hutang yang besar serta ketidakstabilan perusahaan. Disamping itu, hal ini karena adanya fenomena yang juga mendasari pemilihan judul. Fenomena tersebut yakni adanya regulasi tentang Rokok yang dimulai dengan PP Nomor 109 tentang pengamanan bahan yang mengandung Zat Adiktif berupa produk tembakau bagi kesehatan yang dikeluarkan pemerintah tahun 2012 kemarin yang mengacu pada Framework Convention on Tobacco Control (FCTC) yang dicanangkan Organisasi Kesehatan Dunia (WHO) 2003. Hal ini tentunya dapat berdampak pada penurunan penjualan dan tentunya laba akan berkurang pula

Selain itu, masalah return saham juga dikarenakan laba per lembar saham yang diterima oleh investor. Earning Per Share (EPS) sangatlah penting karena menjadi gambaran seberapa besar keuntungan untuk tiap lembar saham yang dimiliki oleh investor. Tingkat pengembalian untuk tiap lembar saham yang terbesar yakni pada PT Gudang Garam Tbk, sementara yang terkecil yakni pada PT Bentoel International Investama Tbk yang terus mengalami kerugian pada tahun 2102-2016. Kenaikan earning per share berarti perusahaan sedang dalam tahap pertumbuhan atau kondisi keuangannya sedang mengalami peningkatan dalam penjualan dan laba, atau dengan kata lain semakin besar earning per share menandakan kemampuan perusahaan dalam menghasilkan keuntungan bersih setiap lembar saham. Masalah krusial yakni terlihat pada perusahaan PT Bentoel International Investama Tbk yang menunjukan bahwa investor harus menanggung kerugian.

Kemudian, masalah juga diidentifikasi dari Price Earning Ratio (PER) Perusahaan Manufaktur Sub Sektor Industri Rokok Yang Terdaftar di Bursa Efek Indonesia cenderung bergerak dan tidak stabil. Dapat pula diketahui bahwa nilai Price Earning Ratio (PER) terbesar yakni pada PT Gudang Garam 
Tbk sementara yang paling kecil yakni pada PT HM Sampoerna Tbk. Kemudian yang nilai Price Earning Ratio (PER) yang bermasalah yakni pada PT Bentoel International Investama Tbk yang bernilai negatif yang menunjukan bahwa adanya penurunan nilai saham.

\section{KAJIAN LITERATUR DAN PENGEMBANGAN HIPOTESIS Return Saham}

Return saham adalah pendapatan yang dinyatakan dalam persentase dari modal awal investasi. Pendapatan investasi dalam saham meliputi keuntungan jual beli saham, di mana jika untung disebut capital gain dan jika rugi disebut capital loss (Samsul, 2006: 291).

\section{Return On Asset}

Menurut Brigham dan Houston (2011: 90) Rasio laba bersih terhadap total aktiva mengukur pengembalian atas total aktiva (ROA) setelah bunga dan pajak. Return On Assets (ROA) mampu mengukur kemampuan perusahaan manghasilkan keuntungan pada masa lampau untuk kemudian diproyeksikan di masa yang akan datang. Pengukuran atau rumus dari Return On Asset mengacu pada Hermuningsih (2012:237) yang dijabarkan berikut ini:

\section{Earning Per Share}

Komponen penting yang harus diperhatikan dalam analisis perusahaan adalah laba per lembar saham atau dikenal sebagai Earning Per Share (EPS). Earning Per Share (EPS) adalah rasio yang mencerminkan kemampuan perusahaan dalam menghasilkan laba untuk setiap lembar saham yang beredar (Darmaji, 2011: 139). Adapun rumus yang digunakan untuk menentukan EPS menurut Fabozzi (2003: 361) adalah sebagai berikut:

\section{Price earning ratio}

Price earning ratio atau juga disebut sebagai earning multiplier. Informasi PER mengindikasikan basarnya rupiah yang harus dibayarkan investor untuk memperoleh satu rupiah earning perusahaan. (Tandelilin, 2007:243). Secara matematis, kita dapat mengestimasi nilai intrinsik saham perusahaan sebagai berikut:

\section{METODE PENELITIAN}

Analisis regresi berganda merupakan analisis regresi yang memprediksi besar variabel tergantung menggunakan data dari dua atau lebih variabel bebas yang telah diketahui besarnya (Santoso, 2012:221). Persamaan regresi berganda adalah:

$$
\mathrm{Y}=\alpha+\beta_{1} \mathrm{X}_{1}+\beta_{2} \mathrm{X}_{2}+\beta_{3} \mathrm{X}_{3}+\varepsilon
$$




\section{HASIL DAN PEMBAHASAN}

\section{HASIL}

\section{Normalitas Data}

Hasil pengujian normalitas disajikan dalam gambar 1 berikut:

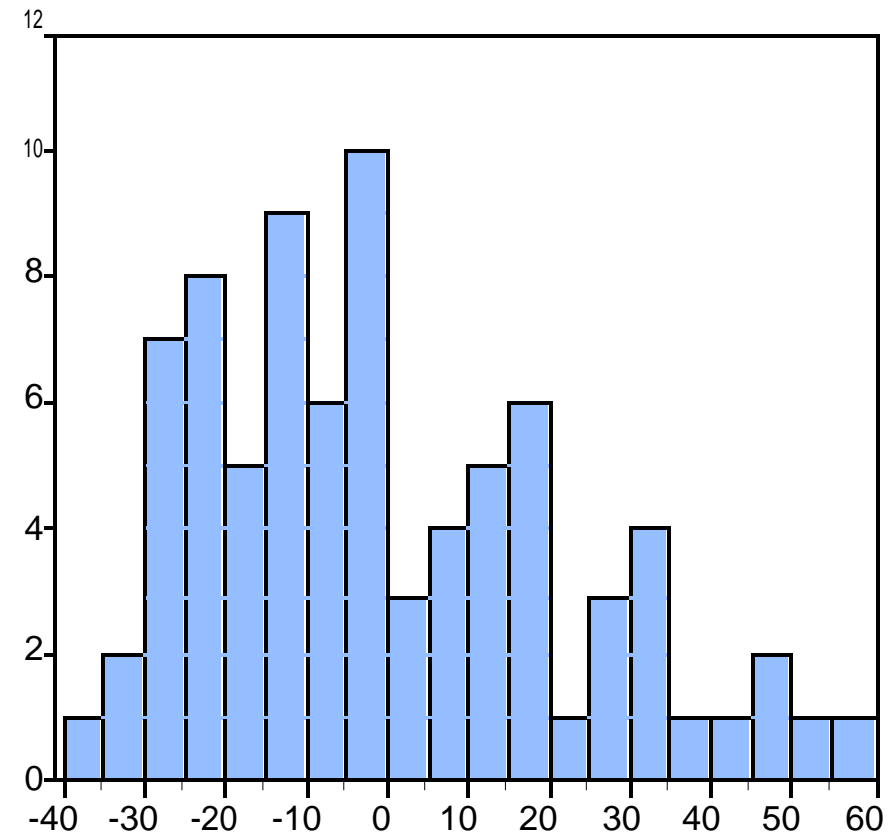

\begin{tabular}{|ll|}
\hline Series: Standardized Residuals \\
Sample 2012Q1 2016Q4 \\
Observations 80 \\
Mean & $-8.88 \mathrm{e}-16$ \\
Median & -3.237771 \\
Maximum & 55.35291 \\
Minimum & -36.26524 \\
Std. Dev. & 22.41565 \\
Skewness & 0.620324 \\
Kurtosis & 2.588081 \\
& \\
Jarque-Bera & 5.696282 \\
Probability & 0.057952 \\
\hline
\end{tabular}

\section{Gambar 1 Hasil Uji Normalitas}

Berdasarkan gambar di atas dapat dilihat bahwa pengujian normalitas data ditemukan bahwa nilai Jarque Bera (JB) yakni sebesar 5,696282 dan probabilitas pengujian yakni sebesar 0,057952. Nilai probabilitas atau signifikansi tersebut lebih besar dari 0,05 sehingga data berdistribusi normal.

\section{Uji Multikolinearitas}

Berdasarkan perhitungan pada lampiran maka VIF yang disajikan berikut ini:

Tabel 1 Pengujian Multikolinearitas

\begin{tabular}{cccc}
\hline Variabel & Nilai R-Square & VIF & Kesimpulan \\
\hline Return On Asset (ROA) & 0.123538 & 1,141 & Non Multikolinearitas \\
Earning Per Share (EPS) & 0.065801 & 1,070 & Non Multikolinearitas \\
Price Earning Ratio (PER) & 0.105870 & 1,118 & Non Multikolinearitas \\
\hline
\end{tabular}

Sumber: Pengolahan Data E-Views 9, 2018.

Berdasarkan hasil pada tabel di atas terlihat bahwa semua variabel bebas memiliki VIF di bawah 10. Nilai VIF Return On Asset (ROA) sebesar 1,141 < 10, nilai VIF Earning Per Share (EPS) sebesar 1,070 < 10 dan nilai VIF Price Earning Ratio (PER) sebesar 1,118 < 10. Dengan demikian dapat disimpulkan bahwa tidak terjadi gejala multikolinearitas.

\section{Pengujian Autokorelasi}

Hasil pengujian autokorelasi dengan metode Durbin Watson ditampilkan pada tabel 2 berikut ini: 
Tabel 2 Hasil Autokorelasi

\begin{tabular}{l} 
Dependent Variable: RETURN_SAHAM? \\
Method: Pooled EGLS (Cross-section random effects) \\
Date: 01/24/18 Time: 15:10 \\
Sample: 2012Q1 2016Q4 \\
Included observations: 20 \\
Cross-sections included: 4 \\
Total pool (balanced) observations: 80 \\
Swamy and Arora estimator of component variances \\
\hline \\
F-statistic \\
Prob(F-statistic)
\end{tabular}

Sumber: Pengolahan Data E-Views 9, 2018

Berdasarkan tabel 2 di atas dapat dilihat bahwa nilai Durbin Watson pengujian sebesar 0,323. Berdasarkan pernyataan Santoso dan Ashari (2005:224) dikemukakan bahwa nilai dw yang memenuhi uji durbin watson jika terletak diantara nilai -2 sampai dengan +2 . Sehingga dapat disimpulkan data dalam kedaan memenuhi uji autokorelasi.

\section{Uji Heterokedastisitas}

Hasil heterokedastisitas dengan uji Glejser ditampilkan berikut ini:

Tabel 3 Pengujian Heterokedastisitas

\begin{tabular}{cccc}
\hline Variabel & Nilai Prob. & Keterangan & Status \\
\hline ROA & 0.9467 & Prob. $>0,05$ & Memenuhi Uji \\
EPS & 0.8574 & Prob. $>0,05$ & Heterokedastisitas \\
PER & 0.1440 & Prob. $>0,05$ & \\
\hline
\end{tabular}

Sumber: Pengolahan Data E-Views 9, 2018

Hasil pengujian heterokedastisitas dengan metode Glejser di atas didapat nilai signifikansi lebih besar dari nilai alpha $(0,05)$ sehingga H0 diterima. Dengan demikian dapat disimpulkan bahwa secara keseluruhan, tidak terjadi gejala heterokedastisitas dalam model regresi.

\section{Penaksiran Model Regresi Berganda (Pengujian Koefisien Regresi)}

Hasil regresi data panel dengan bantuan E-Views 9 ditampilkan pada tabel 4 berikut ini:

\section{Tabel 4 Model Analisis Regresi}

Dependent Variable: RETURN_SAHAM?

Method: Pooled EGLS (Cross-section random effects)

Date: 01/24/18 Time: 15:10

Sample: 2012Q1 2016Q4

Included observations: 20

Cross-sections included: 4

Total pool (balanced) observations: 80

Swamy and Arora estimator of component variances

\begin{tabular}{crrrr}
\hline Variable & Coefficient & Std. Error & t-Statistic & Prob. \\
C & -7.112210 & 3.253132 & -2.186265 & 0.0319 \\
ROA? & 0.284032 & 0.181811 & 1.562238 & 0.1224 \\
EPS? & 0.005722 & 0.002509 & 2.280974 & 0.0254 \\
PER? & -0.164458 & 0.250046 & -0.657711 & 0.5127 \\
\hline
\end{tabular}




\begin{tabular}{|c|c|c|c|}
\hline \multicolumn{4}{|c|}{ Random Effects (Cross) } \\
\hline _GGRM--C & 0.000000 & & \\
\hline _HMSP--C & 0.000000 & & \\
\hline _RMBA--C & 0.000000 & & \\
\hline _WIIM--C & 0.000000 & & \\
\hline R-squared & 0.202328 & Mean dependent var & 1.871679 \\
\hline Adjusted R-squared & 0.170841 & S.D. dependent var & 25.09800 \\
\hline S.E. of regression & 22.85378 & Sum squared resid & 39694.45 \\
\hline F-statistic & 6.425743 & Durbin-Watson stat & 0.323584 \\
\hline Prob(F-statistic) & 0.000616 & & \\
\hline
\end{tabular}

Sumber: Pengolahan Data E-Views 9, 2018

Berdasarkan hasil analisis menggunakan bantuan program E-Views 9 di atas maka diperoleh model regresi sebagai berikut:

$$
\text { Return saham }=-7,112+0,284 \mathrm{X}_{1}+0,005 \mathrm{X}_{2}-0,164 \mathrm{X}_{3}+0,797672 \mathrm{e}
$$

\section{Hasil Uji Parsial (Uji t)}

1. Pengaruh Return On Asset (ROA) terhadap Return saham pada Perusahaan Manufaktur Sub Sektor Industri Rokok yang Terdaftar di BEI yang terdaftar di BEI periode 2012-2016

Berdasarkan analisis diperoleh nilai thitung untuk variabel Return On Asset (ROA) sebesar 1.562238. Jika dibandingkan dengan nilai tabel yang sebesar 1,992. Maka thitung yang diperoleh lebih kecil dari nilai tabel. Nilai signifikansi Return On Asset (ROA) lebih besar dari nilai probabilitas 0,05 , atau nilai $(0.1224>0,05)$. Sehingga dengan demikian dapat disimpulkan bahwa pada tingkat kepercayaan 95\% (alpha 0,05) Return On Asset (ROA) tidak berpengaruh signifikan terhadap Return saham pada Perusahaan Manufaktur Sub Sektor Industri Rokok yang Terdaftar di BEI selama periode 2012-2016.

2. Pengaruh Earning Per Share (EPS) terhadap Return saham pada Perusahaan Manufaktur Sub Sektor Industri Rokok yang Terdaftar di BEI yang terdaftar di BEI periode 2012-2016

Berdasarkan analisis diperoleh nilai thitung untuk variabel Earning Per Share (EPS) sebesar 2.280974. Jika dibandingkan dengan nilai t tabel yang sebesar 1,992. Maka thitung yang diperoleh lebih besar dari nilai tabel. Nilai signifikansi Earning Per Share (EPS) lebih kecil dari nilai probabilitas 0,05 , atau nilai $(0.0254<0,05)$. Sehingga dengan demikian dapat disimpulkan bahwa pada tingkat kepercayaan 95\% (alpha 0,05) Earning Per Share (EPS) berpengaruh signifikan terhadap Return saham pada Perusahaan Manufaktur Sub Sektor Industri Rokok yang Terdaftar di BEI periode 2012-2016.

3. Pengaruh Price Earning Ratio (PER) terhadap Return saham pada Perusahaan Manufaktur Sub Sektor Industri Rokok yang Terdaftar di BEI yang terdaftar di BEI periode 2012-2016

Berdasarkan analisis diperoleh nilai thitung untuk variabel Price Earning Ratio (PER) sebesar 0.657711. Jika dibandingkan dengan nilai tabel yang sebesar 1,992. Maka thitung yang 
diperoleh jauh lebih kecil dari nilai tabel. Nilai signifikansi Price Earning Ratio (PER) lebih besar dari nilai probabilitas 0,05 , atau nilai $(0.5127>0,05)$. Sehingga dengan demikian dapat disimpulkan bahwa pada tingkat kepercayaan 95\% (alpha 0,05) Price Earning Ratio (PER) tidak berpengaruh signifikan terhadap Return saham pada Perusahaan Manufaktur Sub Sektor Industri Rokok yang Terdaftar di BEI periode 2012-2016.

\section{Hasil Uji Simultan (Uji F)}

Berdasarkan tabel di atas didapat nilai F-hitung penelitian ini sebesar 6,425743. Sedangkan nilai F-tabel pada tingkat signifikansi 5\% dan df1 sebesar $k=3$ dan df2 sebesar n-k-1 = 80-3-1 = 76 adalah sebesar 2,72. Jika kedua nilai $\mathrm{F}$ ini dibandingkan, maka nilai F-hitung yang diperoleh jauh lebih besar dibandingkan F-tabel sehingga dan H1 diterima. Dengan demikian secara keseluruhan dapat disimpulkan bahwa variabel bebas (Return On Asset (ROA), Earning Per Share (EPS), Price Earning Ratio (PER)) secara bersama-sama berpengaruh signifikan terhadap variabel terikat Return saham Perusahaan Manufaktur Sub Sekor Industri Rokok yang Terdaftar di BEI periode 2012-2016.

\section{Interpretasi Koefisien Determinasi}

Berdasarkan tabel di atas, maka nilai koefisien determinasi adjusted $R^{2}$ sebesar 0,202328. Nilai ini berarti bahwa sebesar 20,2328\% besarnya Return saham Perusahaan Manufaktur Sub Sektor Industri Rokok yang Terdaftar di BEI dapat dijelaskan oleh Return On Asset (ROA), Earning Per Share (EPS) dan Price Earning Ratio (PER). Hal ini dapat pula disimpulkan bahwa variabel-variabel bebas mampu menjelaskan atau memberikan informasi yang dibutuhkan untuk memprediksi variabel terikat.

\section{PEMBAHASAN}

\section{Pengaruh Return On Asset (ROA) terhadap Return saham Perusahaan Manufaktur Sub Sektor Industri Rokok yang Terdaftar di BEI yang Terdaftar di BEI periode 2012-2016}

Hasil deskriptif menunjukan bahwa Rasio ini memiliki nilai terendah sebesar -22,230\%. Sedangkan nilai tertinggi sebesar 39,477\%. Adapun rata-rata Return On Asset (ROA) dan standar deviasinya masing-masing sebesar $9,780 \%$ dan $17,652 \%$. Nilai rata-rata Return On Asset (ROA) yang lebih kecil dibandingkan dengan nilai standar deviasi mengindikasikan bahwa nilai rata-rata bukan merupakan representasi yang baik untuk menggambarkan data Return On Asset (ROA) secara keseluruhan.

Hasil regresi menunjukan bahwa Return On Asset (ROA) tidak berpengaruh signifikan terhadap Return saham pada Perusahaan Manufaktur Sub Sektor Industri Rokok yang Terdaftar di BEI selama periode 2012-2016. Nilai t positif menunjukkan bahwa Return On Asset (ROA) mempunyai hubungan yang searah dengan Return saham. Dengan kata lain semakin besar Return On Asset (ROA) maka akan menjadi sinyal bagi investor untuk tertarik dengan saham perusahaan sehingga harganya menjadi lebih mahal, hal inilah yang membuat return saham perusahaan menjadi lebih tinggi.

Return On Asset (ROA) tidak berpengaruh signifikan terhadap Return saham karena keuntungan yang dimiliki oleh perusahaan tidak sepenuhnya atau lebih besar yang dijadikan laba ditahan sehingga proporsi dividen menjadi berkurang. Pada dasarnya keuntungan yang dimiliki oleh perusahaan ada baiknya lebih banyak dibagikan sebagai dividen agar masyarakat atau investor menjadi lebih tertarik dengan perusahaan sehingga dapat meningkatkan capital 
gain. Selain itu tidak signifikannya pengaruh Return On Asset (ROA) terhadap Return saham karena terdapat 1 perusahaan yang mengalami kerugian yakni pada perusahaan PT Bentoel Intenational Tbk

Secara statistik telah dijelaskan bahwa pengaruh yang signifikan ini akibat dari nilai thitung yang lebih kecil dari nilai tabel. Sementara berdasarkan fenomena hal ini diakibatkan oleh faktor bahwa perusahaan dengan tingkat aset yang tinggi serta aset yang tumbuh dengan baik maka akan membuat perusahan dikategorikan sebagai perusahaan yang besar sehingga jumlah pajak yang akan dibayarkan pun akan semakin besar. Dismaping itu, mengenai aset tentunya sangat berhubungan erat dengan agency theory yang didalamnya membahsa mengenai kecurangan dari manajemen dalam rangka untuk mendapatkan bonus atas kinerja keuangan yang baik. Sehingga faktor ini bukanlah faktor yang akurat yang dapat meningkatkan return saham perusahaan pakan ternak.

Secara keseluruhan dapat dikatakan bahwa hasil penelitian ini yakni tidak terdapat pengaruh yang signifikan dengan koefisien regresi positif. Hasil penelitian ini sejalan dengan penelitian yang dilakukan oleh Ahmed Imran Hunjra, Muhammad Shahzad Ijaz, Muhammad Irfan Chani, Sabih ul Hassan Dan , Umer Mustafa (2014) yang berjudul Impact of Dividend Policy, Earning per Share, Return on Equity, Prot after Tax on Stock Prices. Hasil menunjukkan pendapatan deviden dan rasio pembayaran dividen deviden yang ingin hal yang sakral itu telah langkah-langkah kebijakan dampak signifikan pada harga saham.

\section{Pengaruh Earning Per Share (EPS) terhadap Return saham Perusahaan Manufaktur Sub Sektor Industri Rokok yang Terdaftar di BEI yang terdaftar di BEI periode 2012- 2016}

Hasil pengujian deskriptif menunjukan bahwa rasio ini memiliki nilai terendah sebesar Rp -314,739 per lembar saham. Sedangkan nilai tertinggi sebesar Rp 3.467,971 per lembar saham. Adapun rata-rata Earning Per Share (EPS) dan standar deviasinya masing-masing sebesar Rp 1.276,437 per lembar saham dan Rp.1.405,380 per lembar saham. Nilai rata-rata Earning Per Share (EPS) yang lebih kecil dibandingkan dengan nilai standar deviasi mengindikasikan bahwa nilai rata-rata bukan merupakan representasi yang baik untuk menggambarkan data Earning Per Share (EPS).

Sebagaimana hasil pengujian regresi ditemukan bahwa Earning Per Share (EPS) berpengaruh signifikan terhadap Return saham pada Perusahaan Manufaktur Sub Sektor Industri Rokok yang Terdaftar di BEI periode 2012-2016. Nilai t positif menunjukan bahwa Earning Per Share (EPS) mempunyai hubungan yang searah dengan dengan Return saham. Dengan kata lain semakin besar rasio Earning Per Share (EPS) atau semakin besar prospek pertumbuhan laba berish untuk riap lembar saham maka semakin besar rasio Return saham peusahaan

Signifikannya hasil ini menunjukan bahwa invesor melakukan penilaian mengenia kinerja keuangan perusahaan khususnya tingkat EPS perusahaan.sebab salah satu aspek fundamental yang menjadi titik tolak bagi investor untuk menanamkan modalnya adanya tingkat pengembalian yang akan diperoleh atas tiap lembar saham yang dibeli.

Hasil penelitian ini mendukung dan sejalan dengan signal teori sebagaimana yang dikatakan oleh Setiyanto dan Hadi (2013: 4) bahwa Signalling theory menekankan kepada pentingnya informasi yang dikeluarkan oleh perusahaan terhadap keputusan investasi pihak di 
luar perusahaan. Informasi merupakan unsur penting bagi investor dan pelaku bisnis karena informasi pada hakekatnya menyajikan keterangan. Sehingga informasi laba per lembar saham akan membuat investor semakin tertarik dengan saham perusahaan sehingga return saham akan semakin tinggi.

Meskipun angka EPS merupakan representasi yang baik dalam menggambarkan tingkat keuntungan dari suatu perusahaan sebaiknya investor lebih teliti lagi dalam menilai EPS suatu perusahaan. Sebab tingkat EPS yang tinggi bukan berarti bahwa perusahaan tersebut sehat, bisa saja hal tersebut karena jumlah saham yang beredar masih sedikit. Atau dalam hal ini maka alangkah biaknya juga perusahaan memperhatikan kebijakan dalam melakukan stock split sebab kabijakan ini akan berdampak pada tingkat penurunan pada EPS Perusahaan Manufaktur Sub Sektor Industri Rokok yang Terdaftar di BEI.

\section{Pengaruh Price Earning Ratio (PER) terhadap Return saham Perusahaan Manufaktur Sub Sektor Industri Rokok yang Terdaftar di BEI yang Terdaftar di BEI periode 2012- 2016}

Hasil analisis deskriptif menunjukan bahwa Rasio ini memiliki nilai terendah sebesar Rp 13,434. Dengan nilai tertinggi sebesar Rp 24,519. Adapun rata-rata Price Earning Ratio (PER) adalah sebesar Rp 6,675 dengan standar deviasi yakni sebesar Rp 10,685. Nilai ratarata Price Earning Ratio (PER) yang lebih kecil dibandingkan dengan nilai standar deviasi mengindikasikan bahwa nilai rata-rata tidak dapat dijadikan acuan dalam menggambarkan data Price Earning Ratio (PER).

Sementara hasil hipotesis menunjukan bahwa Price Earning Ratio (PER) tidak berpengaruh signifikan terhadap Return saham pada Perusahaan Manufaktur Sub Sektor Industri Rokok yang Terdaftar di BEI periode 2012-2016. Nilai t negatif menunjukkan bahwa Price Earning Ratio (PER) mempunyai hubungan yang tidak searah dengan Return saham. Sehingga peningkatan pada rasio Price Earning Ratio (PER) maka return saham perusahaan akan mengalami penurunan, yang dikarenakan peningkatan Price Earning Ratio (PER) dapat menjadi 2 tanda yakni overvalued (harga saham terlalu mahal) pada harga saham dan rendahnya nilai laba per lembar saham

Hasil yang tidak signifikan karena Price Earning Ratio (PER) Perusahaan Manufaktur Sub Sektor Industri Rokok karena terdapat 1 perusahaan yakni PT Bentoel International Investama Tbk yang nilai Price Earning Ratio (PER) nya negatif sehingga hal tersebut tidak mampu merepresentasikan hasil yang baik bagi sub sektor industri rokok yang Terdaftar di BEI. Kemudian hasil yang negatif dikarenakan adanya peningkatan Price Earning Ratio (PER) menjadi tanda mahalnya sebuah saham sehingga menjadi salah satu aspek yang mengurangi keinginan investor dalam berinvestasi.

Hasil dari pengujian hipotesis ketiga sejalan dengan hasil penelitian yang dilakukan oleh Risdiyanto dan Suhermin (2016) yang menemukan bahwa return on investment dan earning per share tidak berpengaruh terhadap return saham,s edangkan price earning ratio berpengaruh negatif signifikan terhadap return saham. Return Saham sebagai variabel terikat. Analisis yang digunakan dimana datanya lebih banyak. 
Pengaruh Return On Asset (ROA), Earning Per Share (EPS), Price Earning Ratio (PER) terhadap Return saham Perusahaan Manufaktur Sub Sektor Industri Rokok yang Terdaftar di BEI yang Terdaftar di BEI periode 2012-2016

Hasil pengujian menunjukan bahwa variabel bebas (Return On Asset (ROA), Earning Per Share (EPS), Price Earning Ratio (PER)) secara bersama-sama berpengaruh signifikan terhadap variabel terikat Return saham Perusahaan Manufaktur Sub Sekor Industri Rokok yang Terdaftar di BEI periode 2012-2016. sebesar 20,2328\% besarnya Return saham Perusahaan Manufaktur Sub Sektor Industri Rokok yang Terdaftar di BEI dapat dijelaskan oleh Return On Asset (ROA), Earning Per Share (EPS) dan Price Earning Ratio (PER). Hal ini dapat pula disimpulkan bahwa variabel-variabel bebas mampu menjelaskan atau memberikan informasi yang dibutuhkan untuk memprediksi variabel terikat

Adapun pengaruh dari variabel lain terhadap Return saham sebesar 79,7672\% (100\%$20,2328 \%$ ). Variabel lain yang dapat mempengaruhi return saham tersebut yakni faktor dalam kategori fundamental dan kategori teknikal. Faktor fundamental dapat berupa Return on Equity, net profit margin, debt to equity ratio, debt to asset ratio, current ratio, rasio aktivitas dan rasio pasar lainnya. Sementara itu faktor teknikal meiputi perkembangan kurs, suku bunga, inflasi serta pertumbuhan ekonomi.

\section{KESIMPULAN DAN SARAN}

\section{KESIMPULAN}

Berdasarkan hasil penelitian dan pembahasan pada bab sebelumnya, maka dapat ditarik beberapa simpulan sebagai berikut:

1. Return On Asset (ROA) tidak berpengaruh signifikan terhadap Return saham pada Perusahaan Manufaktur Sub Sektor Industri Rokok yang Terdaftar di BEI selama periode 2012-2016.

2. Earning Per Share (EPS) berpengaruh signifikan terhadap Return saham pada Perusahaan Manufaktur Sub Sektor Industri Rokok yang Terdaftar di BEI periode 2012-2016.

3. Price Earning Ratio (PER) tidak berpengaruh signifikan terhadap Return saham pada Perusahaan Manufaktur Sub Sektor Industri Rokok yang Terdaftar di BEI periode 20122016.

4. Return On Asset (ROA), Earning Per Share (EPS), Price Earning Ratio (PER) secara bersama-sama berpengaruh signifikan terhadap variabel terikat Return saham Perusahaan Manufaktur Sub Sekor Industri Rokok yang Terdaftar di BEI periode 2012-2016. sebesar 20,2328\% besarnya Return saham Perusahaan Manufaktur Sub Sektor Industri Rokok yang Terdaftar di BEI dapat dijelaskan oleh Return On Asset (ROA), Earning Per Share (EPS) dan Price Earning Ratio (PER).

\section{SARAN}

Berdasarkan hasil penelitian dan simpulan yang telah diuraikan di atas, maka saran penelitian ini adalah sebagai berikut:

1. Bagi perusahaan untuk memaksimlakan fungsi aktiva dan komponen yang ada di dalamnya dalam rangka untuk menarik minat investor dalam menanamkan sahamnya pada perusahaan. Salah satunya yakni dengan mengalokasikan lebih banyak pada aktiva tetap 
agar hasilnya lebih produkktif dalam menghasilkan atau memproduksi barang dagangan perusahaan

2. Perlunya bagi perusahaan terus memaksimalkan laba dalam rangka untuk menarik minat investor sehingga nilai perusahaan (harga saham) akan semakin besar. Implikasi langsung dari peningkatan harga saham yakni akan meningkatkan harga Saham perusahaan tersebut. Langkah yang perlu dilakukan dengan meningkatkan penjualan sehingga laba akan semakin besar.

3. Bagi perusahaan untuk terus memaksimalkan rasio pasar dan menjadikan nilai PER sebagai acuan ketika akan melakukan Stock Split..

4. Bagi penelitian selanjutnya diharapkan dapat merekonstruksi penelitian dengan menganalisis harga Saham serta faktor-faktor fundamental dan teknikal yang dapat berakibat pada harga saham perusahaan. Seta merekonstruksi analisis data dengan penggunaan Path Analysis, MRA atapun TSLS.

\section{REFERENSI}

Basyori, Kurnia. (2008). Analisis Pengaruh Pengumuman Dividen Terhadap Return Saham. Yogyakarta: Fakultas Ekonomi Universitas Islam Indonesia.

Brigham Eugene F, dan Houston J.F. (2006). Manajemen Keuangan. Buku 11 Edisis Kedelapan Terjemahan. Suharto, Dodo dan Wibowo, Herman. Jakarta: Erlangga.

Darmadji, Tjiptono dan Fakhrudin, Hendy M. (2011). Pasar modal di Indonesia Pendekatan Tanya Jawab. Jakarta: Salemba Empat.

Fahmi, Irham. (2012). Analisis Laporan Keuangan. Cetakan Ke-2. Bandung: Alfabeta

Hanafi, Mahmud. (2008). Manajemen Keuangan. Edisi Pertama. Yogyakarta: BPFEYogyakarta.

Husnan, Suad. (2005). Dasar-Dasar Teori Portfolio dan Analisis Sekuritas. Edisi Keempat. Cetakan Pertama.UPP AMP. YKPN.

Jogiyanto, H.M. (2010). Teori Portofolio dan Analisis Investasi. Edisi Ketujuh. Yogyakarta: Penerbit BPFE.

Jogiyanto, Hartono. (2004). Metodologi Penelitian Bisnis: Salah Kaprah dan PengalamanPengalaman. Yogyakarta: Penerbit Universitas Gadjah Mada

Usman, Marzuki. (2010). ABC Pasar Modal Indonesia. Jakarta: Penerbit Ikatan Sarjana Ekonomi Indonesia.

Wahyudi, Sugeng. (2003). Pengukuran Return Saham. Jurnal Ekonomi, Suara Merdeka

Weston. J. Fred dan Brigham, Eugene F. (2001). Dasar-Dasar Manajemen Keuangan. Jakarta; Erlangga.

Nicky Nathaniel SD, ST. (2008). Analisis faktor-faktor yang Mempengaruhi return saham (Studi Pada Saham-saham Real Estate and Property di Bursa Efek Indonesia Periode 20042006). Tesis. Program Studi Magister Manajemen Program Pasca Sarjana Universitas Diponegoro

Laith Akram Muflih AL - Qudah. (2012). The Factors that affect shares' Return in Amman Stock Market. Interdisciplinary Journal Of Contemporary Research In Business Al-Balqa Applied University 
Şebnem Er dan Bengü Vuran. (2012). Factors Affecting Stock Returns of Firms Quoted in ISE Market: A Dynamic Panel Data Approach. International Journal of Business and Social Research (IJBSR), Volume -2, No.-1

Agustian Effendi. (2014). Analisis Faktor-Faktor Yang Mempengaruhi Return Saham Perusahaan Perbankan yang Terdaftar di BEI Periode Tahun 2009-2012. Jurnal Ilmiah Mahasiswa Jurusan Akuntansi, Fakultas Ekonomi, Universitas Jember (UNEJ). 